\title{
Compliance of the POCT method with the fully automated method for $\mathrm{HbA1c}$ determination
}

\author{
Neda Milinković ${ }^{1 *}$, Marija Sarić Matutinović ${ }^{1}$, \\ Gordana Dmitrašinović ${ }^{1}$, Svetlana Ignjatović ${ }^{1,2}$ \\ ${ }^{1}$ University of Belgrade - Faculty of Pharmacy, Department of Medical Biochemistry, \\ Vojvode Stepe 450, 11221 Belgrade, Serbia \\ ${ }^{2}$ University Clinical Centre of Serbia, Center for Medical Biochemistry, \\ Višegradska 26, 11000 Beograd, Serbia
}

*Corresponding author: Neda Milinković, e-mail: nedan@pharmacy.bg.ac.rs

\begin{abstract}
Previous research suggests that point-of-care (POCT) determination of glycated hemoglobin $(\mathrm{HbAlc})$ is a diagnostic test that can be an adequate alternative to measuring $\mathrm{HbA1c}$ in the laboratory. The main goal of this study was to examine the analytical characteristics of the novel INCLIX POCT method for HbA1c determination in order to test its performance before introducing this method into routine use. HbA1c is measured in a duplicate in 44 EDTA blood samples parallel on INCLIX POCT device (Sugitech, Inc.) and using automated turbidimetric immunoinhibition test on Olympus AU400 (Beckman Coulter). The within run imprecision was $7.58 \%$, between runs imprecision was $6.63 \%$ and $6.22 \%$, and day-to-day imprecision was $8.80 \%$ and $7.51 \%$. Total laboratory imprecision was in agreement with those stated by the manufacturer. A statistically significant Pearson correlation coefficient was calculated $(\mathrm{r}=0.871, \mathrm{P}<0.01$; linear $\mathrm{R}^{2}=0.757$ ). Using Deming regression analysis, the following equation was obtained: $y=$ $1.80+1.304 x$. Our results indicate statistically significant correlation, linear relationship, and a significant degree of compatibility between the two analyzed methods. However, the negative bias of the HbA1c values determined on the POCT analyzer compared to the Olympus AU400 was confirmed, highlighting the need to standardize the INCLIX method.
\end{abstract}

Key words: HbA1c, POCT, diabetes, Deming regression

doi.org/10.5937/arhfarm72-35905 


\section{Introduction}

Glycated hemoglobin ( $\mathrm{HbAlc}$ ) initially emerged as a clinically relevant parameter for long-term assessment of glycemic status and therapy monitoring in patients with diabetes, but also as an additional marker to diagnose diabetes $(1,2)$. So far, a major step and advancement in the standardization of HbAlc determination has been achieved ( 1 , 2). According to the American Diabetes Association (ADA), the generally accepted clinical criteria for diabetes based on the National Glycohemoglobin Standardization Program (NGSP) is: HbAlc less than 5.7\% excludes diabetes, values from $5.7 \%$ to $6.4 \%$ indicate an increased risk for diabetes, while for $\mathrm{HbAlc} \geq 6.5 \%$ the diagnosis of diabetes is made (3). However, the analytical aspect of HbAlc determination is still being investigated (4-8). HbAlc is determined in routine laboratories by various methods on automated analyzers (HPLC ion exchange technique, capillary electrophoresis, affinity chromatography, immunoassays and enzymatic assays). For all automated methods, $\mathrm{HbA1c}$ results are standardized according to the International Federation of Clinical Chemistry (IFCC) Reference Measurement Procedure (RMP) in accordance with the NGSP (9-12). As the requirements for the HbAlc test are high and constantly growing, it is necessary that the determination of this parameter is accessible, efficient, justified and cost-effective. Point-of-care (POCT) determination of HbAlc is a diagnostic test that can be an adequate alternative to measuring HbAlc in the laboratory (13-15). The results are available in a short period of time, immediately after the blood draw, which enables quick medical decisions, thus improving the efficiency of the health system. POCT methods are suitable for patients because they reduce frequent visits to laboratories or doctor's offices and allow the availability of testing in rural areas as well. The use of POCT devices enables capillary sampling of $\mathrm{HbAlc}$, which is important for both pediatric patients and the elderly with poor and difficult to access veins. In order for the HbA1c POCT methods to find a wider routine application, it is necessary to test the analytical characteristics of the POCT devices and methods.

The main goal of this study was to examine the analytical characteristics of the novel INCLIX POCT method for HbAlc determination in order to test its performance before introducing this method into routine use. The evaluation of the POCT method was performed by evaluating the following statistical parameters: within run imprecision (repeatability), day-to-day imprecision (reproducibility), between runs imprecision, and within laboratory imprecision. In addition, the samples were run on the INCLIX analyzer and the Beckman Coulter Olympus AU400 Biochemistry Analyzer in parallel to assess the method agreement.

\section{Experimental section}

\section{Study design}

The study was conducted in June 2019 at the Laboratory for Medical Biochemical Analysis (LMBA), University of Belgrade - Faculty of Pharmacy, Belgrade, Serbia. The following guidelines published by the Clinical and Laboratory Standards Institute (CLSI) 
were used in this study for the evaluation of the INCLIX POCT analyzer: CLSI document EP09-A3, "A Guide to Comparing Measurement Procedures and Determining Bias Using Patient Samples", third revised Edition, published in 2018; CLSI Document EP15-A3, "Guide to Accuracy Verification and Bias Assessment", Third Revised Edition, published in 2017; CLSI Document EP05-A3, "Guide to Accuracy Evaluation of Quantitative Measurement Procedures", third revised edition, published in 2018; and the "Guide to the Evaluation of POCT Instruments," published by the 2012 Australian Association of Clinical Biochemists (AACB) (16-19).

\section{Materials}

To provide a uniform distribution of samples in the whole range of measurements and adequately assess the performance of the analyzed test method specified by the manufacturer, 44 whole blood EDTA samples with low, normal and high HbA1c levels were selected. The concentrations of HbAlc in the analyzed samples covered a clinically significant range of measurements for making and/or excluding the diagnosis of diabetes, and for making the decision to initiate or change therapy (from 5.2\% to $11.8 \%$ ). Samples were measured on the same day in duplicate on INCLIX POCT and Olympus AU400 analyzer. The recommendation not to exceed two hours between sampling on two analyzers was followed.

\section{Methods}

Rapid determination of whole blood HbAlc (recommended anticoagulant is dipotassium/tri-potassium ethylene-diamine-tetra-acetic acid, $\mathrm{K}_{2} / \mathrm{K}_{3}$ EDTA) by INCLIX POCT method uses "sandwich" immunoassay technology based on an antigen-antibody complex formation, visualized by the gold marked detection antibody (20). This method uses $5 \mu \mathrm{L}$ whole blood sample or capillary blood sample that is collected using a capillary or automatic pipette. The results are automatically calculated by the INCLIX analyzer software and the HbA1c concentration can be verified immediately. HbAlc concentration is expressed in \%, which is based on the study of Diabetes Control and Complications Trial (DCCT) and NGSP units $(\%)[\mathrm{HbAlcIFCC}(\mathrm{mmol} / \mathrm{mol})=10.93 \times \mathrm{HbA} 1 \mathrm{cNGSP}$ $(\%)-23.50$ and HbA1cNGSP $(\%)=0.0915 \times \mathrm{HbA} 1 \mathrm{cIFCC}(\mathrm{mmol} / \mathrm{mol})+2.15]$.

The determination of HbA1c on the INCLIX analyzer does not significantly interfere with other bio-molecules, such as bilirubin (up to $684 \mu \mathrm{mol} / \mathrm{L}$ ), triglycerides (up to $11.29 \mathrm{mmol} / \mathrm{L}$ ) and hemoglobin derivatives (acetylated, carbamylated and labile hemoglobin), when using acceptance criteria of $\pm 6 \%$ recovery in relation to the absence of these interferences. Intra- and inter-essay CVs specified by the manufacturer is less than 5\% (20 repeated measurements with three different HbAlc concentrations and 5 repeated measurements, three days, two operators, with three different concentrations of $\mathrm{HbA} 1 \mathrm{c})$. The measurement range of HbAlc expressed in \% on the INCLIX analyzer is from 4 to $14 \%$. INCLIX POCT device is NGSP certified, has CE-IVD approval, but is not IFCC traceable (20). 
Olympus AU400 is a HbA1c fully automated measurement method based on turbidimetric immunoinhibition. This method uses $10 \mu \mathrm{L}$ whole blood sample, pretreated with hemolyzing reagent in a ratio of 1:100 (21). Two-point calibration is used to set total hemoglobin method, and five-point calibration is used for calibration of the HbAlc assay. The calibrator HbA1c values are traceable to the IFCC HbA1c reference method via IFCC HbA1c reference material. The relationship between results from the NGSP network (DCCT aligned) and the IFCC network has been evaluated and a Master Equation (NGSP $=(0.0915 \mathrm{x}$ IFCC $(\mathrm{mmol} / \mathrm{mol}))+2.15)$ has been developed for interconversion of results from IFCC ( $\mathrm{mmol} / \mathrm{mol})$ to NGSP (\%) units. The definition of the relationship between the two networks links IFCC traceable results to clinically meaningful HbAlc results from the DCCT and the United Kingdom Prospective Diabetes Study (UKPDS). The Master Equation also provides these DCCT results with traceability to a higher order reference method.

\section{Statistical analysis}

Excel for Windows statistical program, Method Validator statistical program (Version 1.1, MethVal.exe, by Philippe Marquis, Metz, France), MedCalc Software bvba (Version 2.5.0.0., Ostend, Belgium) and IBM SPSS Statistics version 21.0 (Chicago, IL) were used for the statistical analysis of the obtained data. Results are presented as mean $(\overline{\mathrm{X}})$, standard deviation (SD) and coefficient of variation $(\mathrm{CV})$. The normality of the data distribution was checked by the Kolmogorov-Smirnov test. The significance of the difference between the mean values of the two groups of data was analyzed by a paired Student t-test. The Pearson correlation coefficient was used for the correlation analysis. The comparison of the two methods was examined by the Deming regression analysis and graphically presented by Bland-Altman plots.

\section{Results}

The Kolmogorov-Smirnov test to check the normality of the distribution confirmed the normal distribution for each examined group of data for a significance level of 0.05 .

The within run imprecision was examined by successively analyzing the same sample 20 times. The initial value of the sample used to test the within run imprecision was $5.1 \% \mathrm{HbA} 1 \mathrm{c}$. The calculated mean value was $4.95 \% \mathrm{HbA1c}$, SD was 0.375 , and $\mathrm{CV}$ was $7.58 \%$. The calculated deviation (bias) of the measured values in relation to the original value is $0.15 \% \mathrm{HbA} 1 \mathrm{c}$, which is a total of $\pm 2.94 \%$ deviation of the measured values from the original. The calculated standard error of the mean (SEM) is 0.084 , and the obtained $95 \%$ confidence interval (CI) for data distribution is from $4.78 \% \mathrm{HbA} 1 \mathrm{c}$ to $5.11 \% \mathrm{HbA} 1 \mathrm{c}$.

To calculate the day-to-day imprecision, two samples of baseline HbA1c levels of $6.6 \%$ and $7.5 \%$ were used, respectively, which were closest to clinically significant cutoff values for diagnosis and therapy initiation. Both samples were run for five days in triplicate. The recommendations of the guidelines were followed, so that the time difference in the sample measurement on different devices was not longer than two hours. 
The obtained values for data of both analyzed samples for SD for repeatability (SDr) were 0.395 and 0.509 , and $\mathrm{CV}$ for repeatability $(\mathrm{CVr})$ was $8.80 \%$ and $7.51 \%$.

To calculate the between runs imprecision of POCT HbA1c determinations, two samples of initial $\mathrm{HbA} 1 \mathrm{c}$ levels of $6.6 \%$ and $7.5 \%$ were used and measured for five days in triplicate. The obtained SD for between runs imprecision (SDbr) was 0.474 and 0.421 , and $\mathrm{CV}$ for between runs imprecision (CVbr) was $6.63 \%$ and $6.22 \%$.

Intra-laboratory (total laboratory) imprecision (SDtl) was calculated by a combined analysis of day-to-day imprecision and between runs imprecision according to the formula provided by Chesher et al. (22):

$$
\mathrm{SDtl}=\sqrt{\frac{\mathrm{n}-1}{\mathrm{n}} * \mathrm{SDr}^{2}+\mathrm{SDbr}^{2}}
$$

in which $\mathrm{n}$ is the number of repetitions per day, SDr is SD for repeatability, SDbr is $\mathrm{SD}$ for between runs imprecision.

In order to estimate the agreement of the obtained total laboratory imprecision, SDtl with the indicated values of the manufacturer, the following formula was used to calculate verification value $(\mathrm{Vv})$.

$$
\mathrm{Vv}=\frac{\mathrm{SDtl} * \sqrt{\mathrm{C}}}{\sqrt{\mathrm{T}}}
$$

in which $\mathrm{T}$ represents the effective degree of freedom to assess the accuracy within the laboratory, $\mathrm{C}$ is the $1-\alpha / \mathrm{q}$ percentage point of the Chi-square distribution, $\alpha$ is the false rejection rate and $\mathrm{q}$ is the number of levels tested. To calculate $\mathrm{C}, \alpha$ is traditionally taken as $5 \%$ and $\mathrm{q}$ is equal to 2 (22). $\mathrm{T}$ is calculated according to the following formula:

$$
\mathrm{T}=\frac{\left((\mathrm{n}-1) * \mathrm{SDr}^{2}+\left(\mathrm{n} * \mathrm{SDbr}^{2}\right)\right)^{2}}{\left(\frac{\mathrm{n}-1}{\mathrm{D}}\right) * \mathrm{SDr}^{4}+\left(\frac{\mathrm{n}^{2} * \mathrm{SDbr}^{4}}{\mathrm{D}-1}\right)}
$$

in which $\mathrm{D}$ is the total number of days and $\mathrm{n}$ is the number of repetitions per day. The calculated SDtl is 0.699 and is less than the calculated Vv for within the laboratory imprecision, which is 0.909 , which indicates that the data for within the laboratory imprecision are in agreement with those stated by the manufacturer.

In order to check the inaccuracy and systematic error, we compared the tested POCT method for HbAlc on the INCLIX analyzer with the method of turbidimetric immunoinhibition on the Olympus AU400 biochemical analyzer. The first step was to check the distribution of the analyzed data by the Kolmogorov-Smirnov test. The obtained SD and the level of statistical significance for both groups of data showed that the distribution of $\mathrm{HbA} 1 \mathrm{c}$ concentrations did not deviate significantly from the normal 
Gaussian curve. Statistical parameters were, respectively, for INCLIX and Olympus AU400 analyzer $6.89 \pm 1.28, \mathrm{P}=0.123$ and $6.67 \pm 1.01, \mathrm{P}=0.170$. The bias between methods was 0.3 and the relative bias was $4.5 \%$.

A statistically significant Pearson correlation coefficient was calculated (for the two-way test, the correlation coefficient was 0.871 (linear $\mathrm{R}^{2}=0.757$ ) for the significance level $\mathrm{P}<0.01$ ), which is shown in Figure 1, which indicates a linear relationship between the tested methods.

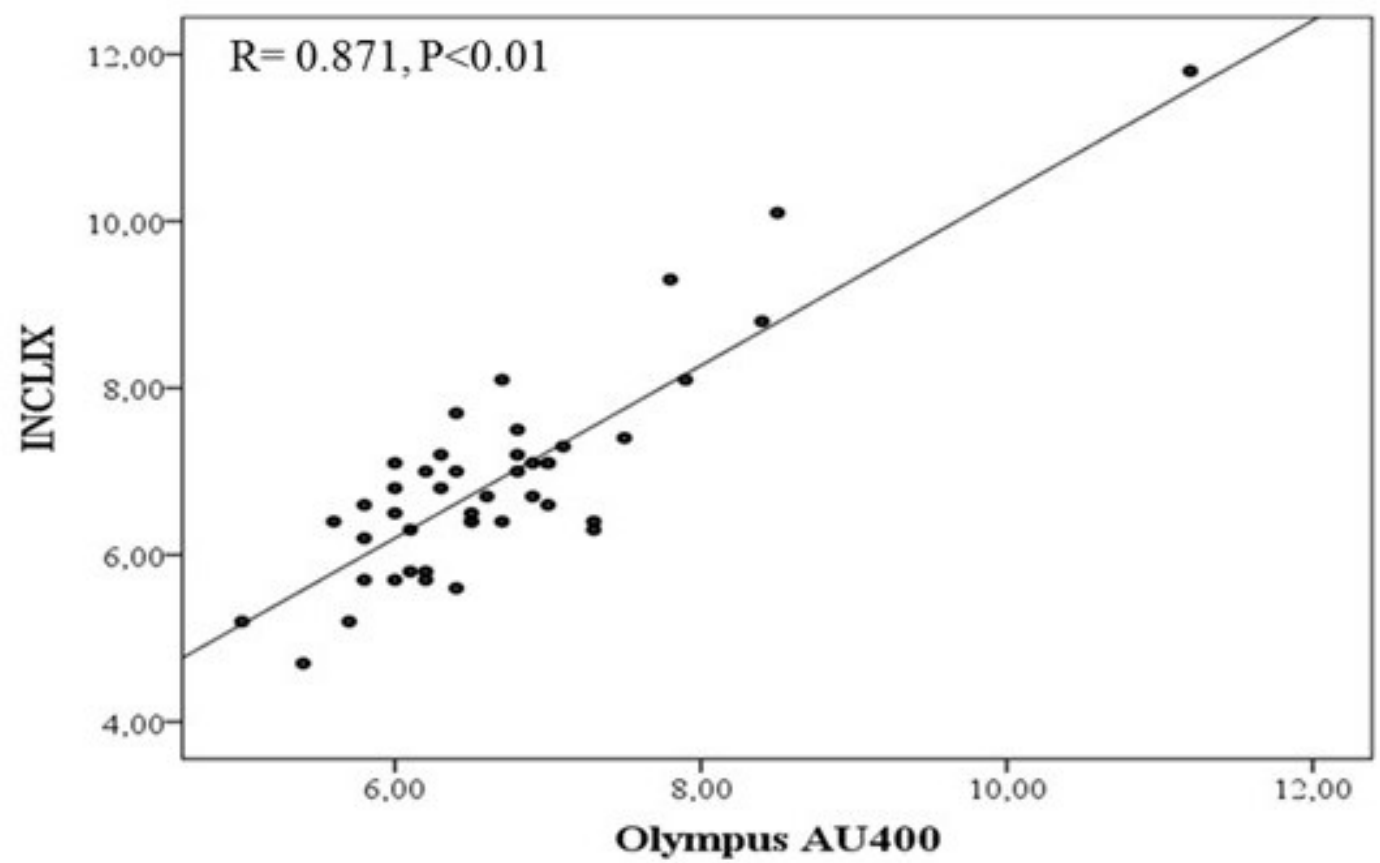

Figure 1. Correlation analysis for INCLIX POCT analyzer and Olympus AU400 biochemical analyzer for the Hb1Ac determination.

Slika 1. Analiza korelacije INCLIX POCT analizatora i Olympus AU400 biohemijskog analizatora za određivanje Hb1Ac.

Using the Deming regression analysis, the following equation was obtained: $y=$ $1.80+1.304 \mathrm{x}$. The value of the intercept is constant deviation, and the value of the slope is proportional deviation in the measurements between the two tested methods. When the numerical values of the intercept and slope are generally analyzed, the values of the $95 \%$ CI are always observed. If the number 0 is within the $95 \%$ confidence interval for the intercept and the number 1 is within the $95 \% \mathrm{CI}$ for the slopes, there is considered to be a statistically significant agreement of the methods. In this study, the $95 \%$ confidence limit interval for the intercept was -4.90 to 1.29 . The obtained values of $95 \%$ confidence limits for the intercept included the value 0 , from which we can conclude that there was no statistically significant difference between the values of the intercept and 0 , i.e. that there was no constant deviation between the methods (Figure 2). The 95\% confidence 
limit interval for the slope was 0.827 to 1.781 . The obtained $95 \%$ confidence interval for slope includes the value of 1 , from which we can conclude that there was no statistically significant deviation between the value of the slope and 1, suggesting that there was no proportional deviation in the measurement using both methods (Figure 2).

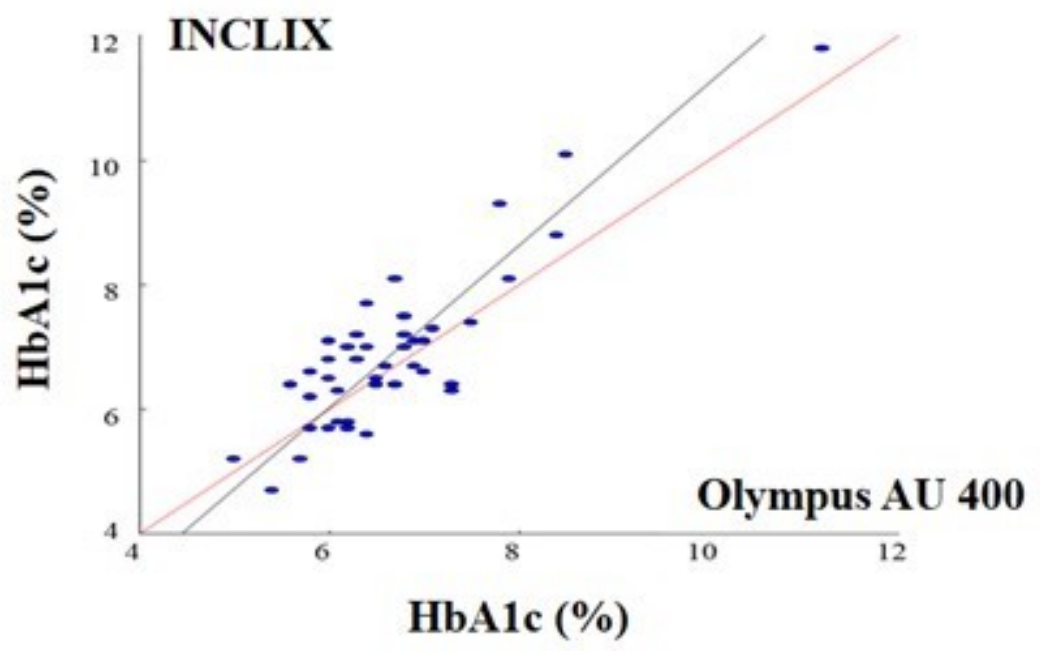

Figure 2. Unadjusted Deming regression analysis $(\mathrm{N}=44)$.

Slope: 1.304 (95\% CI: 0.827 to 1.781$)$

Intercept: -1.80 (95\% CI: -4.90 to 1.29$)$

Slika 2. Nekorigovana Deming regresiona analiza $(\mathrm{N}=44)$.

Nagib: 1,304 (95\% CI: 0,827 do 1,781)

Odsečak: $-1,80$ (95\% CI: $-4,90$ do 1,29$)$

Based on the calculated statistical parameters, it was concluded that the agreement of the examined methods did not deviate significantly from the linearity, so we continued to use the Bland-Altman analysis. The Bland-Altman analysis is a graphical method for comparing two measurement techniques, which analyzes the difference between pairs determining the same samples. The Bland-Altman graph is a scatter diagram in which the mean value of the difference between measurement pairs $(\mathrm{X}-\mathrm{Y})$ is shown on the $\mathrm{Y}$ axis, and the mean value of the measurement $(\mathrm{X}+\mathrm{Y}) / 2$ is shown on the $\mathrm{X}$ axis. In other words, the difference between the pairs of measurements of the same samples is presented on the $\mathrm{Y}$ axis, and the mean value obtained through the two measurements is shown on the $\mathrm{X}$ axis. The Bland-Altman analysis recommends that $95 \%$ of the points be within the \pm SD determination pair difference. If the confidence interval of the mean difference between the methods includes 0 , it is concluded that there is no constant deviation between the methods. Another way of showing the agreement of methods using the Bland-Altman analysis involves representing the relative difference of the determination pairs (\%) on the $\mathrm{Y}$ axis. Based on the graphs of the percentage difference in determination, it is determined whether there is a percentage deviation between the methods. If the 
confidence interval of the percentage mean difference between the methods includes 0 , it is concluded that there is no proportional deviation between the methods. Graphs obtained by the Bland-Altman analysis are shown in Figure 3.

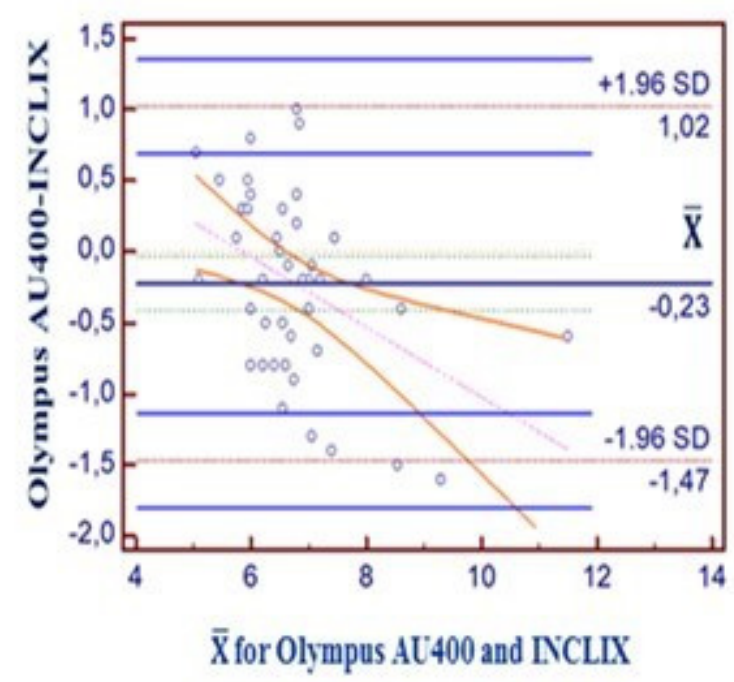

A

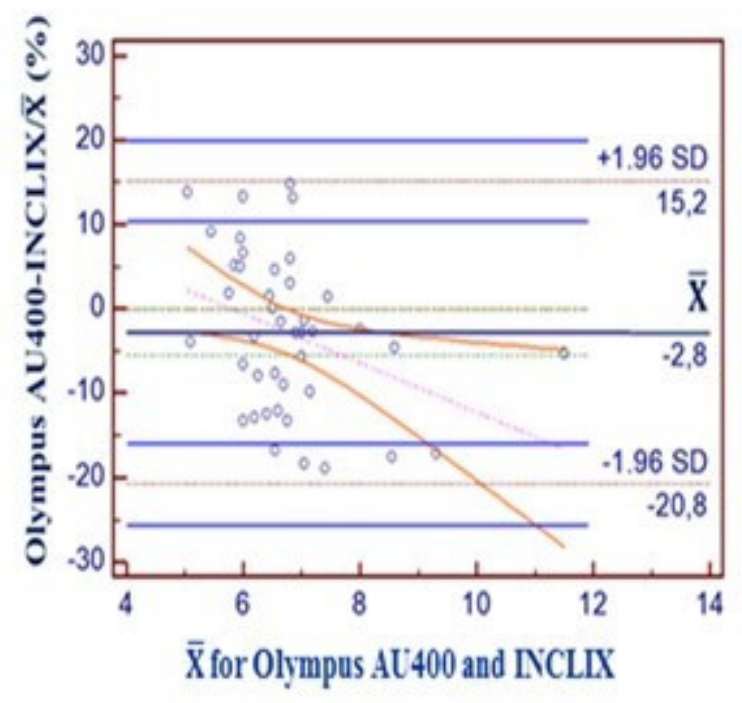

B

Figure 3. Bland-Altman analysis: A, constant deviation of the methods; B, proportional deviation of the methods.

Slika 3. Bland-Altman analiza: A, konstantno odstupanje metoda; B, proporcionalno odstupanje metoda.

Based on the graphical presentations, it can be wrongly concluded that there is a constant deviation between the methods (however, 95\% CI for the mean difference of the pairs of determinations includes 0 , and is -4.90 to 1.29 ). However, the results indicate that there is no proportional deviation between the values obtained by these methods (95\% CI relative to the mean difference of the pairs of determination includes 1 , and is 0.827 to 1.781). The calculated percentage mean difference of the results determined on the INCLIX analyzer in relation to the Olympus AU400 was $-2.8 \%$, which indicates the need to standardize the INCLIX method.

\section{Discussion}

To our knowledge, this is the first study that examines the compliance of the INCLIX POCT method with the fully automated method for determination of HbA1c. In this study, we initially examined the basic performance specifications of the POCT method for HbAlc determination. For optimal performance of the method, it is necessary to know the biological variability of HbAlc. The latest meta-analysis data for biological variability for $\mathrm{HbA} 1 \mathrm{c}$ indicates significantly low values of intra- and inter-individual $\mathrm{CV}$ : 1.6\%, 95\% CI: 1.3-2.5 and 7.1\%, 95\% CI: 6.8-7.5, respectively (23). However, the studies 
are mainly related to the determination of $\mathrm{HbAlc}$ on biochemical analyzers. Although the general accuracy and clinical significance of POCT HbAlc determination has been confirmed, the estimated intra- and inter-individual $\mathrm{CV}$ were still up to $10 \%$ for some POCT analyzers $(6,24-25)$. The manufacturer Sugentech Inc. indicates a significantly low imprecision of the INCLIX method $(<5 \%)(20)$. Our research confirmed that in a routine laboratory environment the analytical characteristics for total laboratory imprecision for INCLIX HbA1c were met. Zhelev et al. (26) have shown that over time the analytical characteristics of various POCT HbA1c methods have significantly improved and that the values of $\mathrm{HbA} 1 \mathrm{c}$ are determined with significantly low analytical imprecision.

Based on the graphical presentations (Figure 3) in this study for proportional and constant deviation between POCT and automated HbAlc determination, it can be wrongly concluded that there was a constant deviation between the methods (however, 95\% CI for the mean difference of the pairs of determinations includes 0 ). On the other side, the calculated results indicated that there was no proportional deviation between the values obtained by the analyzed methods (relative to the mean difference of the determination pairs includes 0 ). The calculated deviation represents the negative bias of the results determined on the INCLIX analyzer $(-2.8 \%)$ in relation to the Olympus AU400, which indicates the need to standardize the INCLIX method. English et al. (1) described in detail the obstacles that were imposed in the process of standardization of the determination of HbAlc. Although significant progress has been made in the standardization of HbAlc determination, it has largely culminated for fully automated methods. For POCT analyzers, the accuracy of the determination of the HbAlc is ensured by appropriate calibration and the use of certified reference material provided by the manufacturer. However, most POCT analyzers do not perform calibration routinely but use a calibration factor that is predetermined by the manufacturer and cannot be adjusted $(1,27-29)$.

The principles of determining HbA1c on POCT devices differ as with automated analyzers. One way to assess the utility of the POCT method is through laboratory evaluation. Another mechanism is through participation in external quality control and proficiency testing. However, most POCT methods are not yet included in these programs. Therefore, it is important that the determination of POCT HbA1c is carried out in compliance with the basic quality requirements for such instruments. In addition to educating and training users, it is important to respect the quality system of conducting such POCT analysis. Ørvim Sølvik et al. (30) have shown that Norwegian community pharmacies can perform internal and external quality assessment on a HbA1c POCT instrument, and the performance is comparable to that of general practitioners offices. Similar studies have been conducted in Switzerland, Australia, and Spain, and the authors have concluded that it is feasible to implement services for diabetes risk assessment in a community pharmacy setting using HbA1c or glucose POCT instruments (31-34).

The presence of deviations in terms of lower HbAlc values measured by the INCLIX apparatus is not unexpected, given that these are two different methods and a 
significant effect of the preanalytical phase in both methods on the overall determination procedure should be taken into account. Barron et al. (35) have conducted a wellcontrolled prospective study and have also reported that POCT HbAlc was associated with significantly lower HbAlc values when compared with laboratory-measured referrals. However, the question arises as to whether this difference in value may be more detrimental to diabetic or non-diabetic patients. Van Raalten et al. (36) have reported that POCT HbA1c measurements showed a high level of agreement with the laboratory test in the outpatient setting, and may be used for preoperative risk profiling in patients prone to cardiometabolic complications. What is certain is that higher HbA1c POCT measurement quality standards are needed for follow-up and therapy decision-making in patients with diabetes to avoid misdiagnosis of diabetes, as well as potential excessive or inadequate treatment of patients at risk for diabetes.

This pilot study had some limitation. First, we have evaluated imprecision as basic performance specification for the routine use of INCLIX HbA1c method. We are aware of the fact that it is important to examine the bias, dynamic range of measurement, the lower limit of detection, quantification and analytical as well as diagnostic specificity and sensitivity. We did not examine diabetic and non-diabetic groups separately, and we have analyzed a relatively small number of patients. Although POCT methods are intended for the determination of HbA1c in a capillary blood sample, for practical reasons we used only venous EDTA blood and not a capillary sample.

\section{Conclusion}

The examined agreement of the INCLIX analyzer with the Olympus AU400 indicates a statistically significant correlation, linear relationship and a significant degree of compatibility between the two analyzed methods. In addition to confirmed analytical characteristics of the method, determining the biological variability of HbAlc by the tested POCT method is recommended, as well as determining the measurement uncertainty of the measurement results on the INCLIX analyzer. In order to harmonize the POCT method on the INCLIX analyzer, conducting external quality control is recommended. However, the final conclusion is that the POCT method of the INCLIX analyzer fulfills all the conditions for routine use of HbAlc determination. However, even for the correct diagnosis, therapy monitoring and prognosis of diabetes mellitus, it is always necessary to determine HbA1c by the same method on the same analyzer.

\section{Acknowledgement}

This work was supported by the Ministry of Education, Science and Technological Development of the Republic of Serbia on the basis of contract No.175036 and No.45103-68/2020-14/200161. 


\section{Disclosure}

Gordana Dmitrašinović works for the company Makler doo Belgrade, Serbia, which provided reagents and the INCLIX analyzer for this study.

\section{References}

1. English E, Lenters-Westra E. HbA1c method performance: The great success story of global standardization. Crit Rev Clin Lab Sci. 2018;55(6):408-419.

2. Lau CS, Aw TC. HbA1c in the diagnosis and management of diabetes mellitus: An update. Diabetes Updates. 2020;6:1-4.

3. American Diabetes Association. Standards of medical care in diabetes-2021. Diabetes Care. 2021;44(Supplement 1):S15-S33.

4. Koga M, Okuda M, Inada S, Ueda S, Nakamura Y, Okumiya T, et al. HbA1c levels measured by enzymatic assay during of-site health checkups are lower than those measured by on-site HPLC assay. Diabetol Int. 2020;11:67-71.

5. Arch BN, Blair J, McKay A, Gregory JW, Newland P, Gamble C. Measurement of HbA1c in multicentre diabetes trials - should blood samples be tested locally or sent to a central laboratory: an agreement analysis. Trials 2016;17:517.

6. Berbudi A, Rahmadika N, Tjahjadi AI, Ruslami R. Performance of Point-of-Care Testing compared with the standard laboratory diagnostic test in the measurement of HbA1c in Indonesian diabetic and nondiabetic subjects. J Diabetes Res. 2020;2020:ID 2037565. doi.org/10.1155/2020/2037565

7. Jalali MT, Bavarsad SS, Hesam S, Afsharmanesh MR, Mohammadtaghvaei N. Assessing agreement between the three common clinical measurement methods of HbA1c. J Diabetes Metab Disord. 2020;19:273-279.

8. EurA1c Trial Group. EurA1c: The European HbA1c trial to investigate the performance of HbA1c assays in 2166 laboratories across 17 countries and 24 manufacturers by use of the IFCC model for quality targets. Clin Chem. 2018;64(8):1183-1192.

9. Standard ISO/TC 212 Clinical laboratory testing and in vitro diagnostic test systems [Internet]. [cited 2022 Jan 07]. Available from: https://www.iso.org/committee/54916.html

10. Jeppsson JO, Kobold U, Barr J, Finke A, Hoelzel W, Hoshino T, et al. Approved IFCC reference method for the measurement of $\mathrm{HbA}(1 \mathrm{c})$ in human blood. Clin Chem Lab Med. 2002;40:78-89.

11. Approved laboratories of the IFCC network laboratories for HbA1c [Internet]. [cited 2022 Jan 07]. Available from:www.ifcchba1c.net/network/approved

12. Weykamp C, John WG, Mosca A, Hoshino T, Little R, Jeppsson JO, et al. The IFCC reference measurement system for HbA1c: a 6-year progress report. Clin Chem. 2008;54:240-248.

13. Erdal GŞ, Işıksaçan N, Koşer M, Kocamaz N. Hemoglobin A1c measurement using Point of Care Testing. Istanbul Med J. 2020;21(1):37-41.

14. Sølvik US, Røraas TCNG, Sandberg S. Diagnosing diabetes mellitus: Performance of hemoglobin A1c point-of-care instruments in general practice offices. Clin Chem. 2013;59:1790-801.

15. Arnold WD, Kupfer K, Little RR, Amar M, Horowitz B, Godbole N, et al. Accuracy and precision of a Point-of-Care HbA1c test. J Diabetes Sci Technol. 2020;14(5):883-889. 
16. Clinical and Laboratory Standards Institute. Measurement procedure comparison and bias estimation using patient samples; approved guideline - Third corrected edition. CLSI document EP09-A3. Clinical Laboratory Standards Institute, Wayne, PA, USA, 2018.

17. Clinical Laboratory Standard Institute. User verification of performance for precision and trueness; approved guideline - Third corrected edition. CLSI document EP15-A2. Clinical and Laboratory Standards Institute, Wayne, PA, USA, 2017.

18. Clinical and Laboratory Standards Institute. Evaluation of precision performance of quantitative measurement methods; approved guideline - Third corrected edition. CLSI document EP05-A2. Clinical Laboratory Standards Institute, Wayne, PA, USA, 2018.

19. Australasian Association of Clinical Biochemists. Guidelines for the Evaluation of PoCT Instruments. [Internet]. [cited 2022 Jan 07]. Available:

https://www.aacb.asn.au/documents/item/244

20. INCLIX HbA1c Test, Instruction for use (2nd revision). Sugentech Inc. Rev.No. IS108E02/2018.08.01.

21. Beckman Coulter manufacturer's manual for HbA1c calibrator [Internet]. [cited 2022 Jan 07]. Available:

https://www.beckmancoulter.com/wsrportal/techdocs?docname=/cis/BLB00389/\%25\%25/EN_Hb A1c_BLB00389.pdf

22. Chesher D. Evaluating assay precision. Clin Biochem Rev. 2008;29:S23-S26.

23. European Federation of Clinical Chemistry and Laboratory Medicine (EFLM) Biological Variation Database. [Internet]. [cited 2022 Feb 02]. Available: https://biologicalvariation.eu/search?q=hba1c

24. Knaebel J, Irvin BR, Xie CZ. Accuracy and clinical utility of a point-of-care HbA1c, testing device. Postgrad Med. 2015;125:91-98.

25. Price CP. Point of care testing. BMJ. 2001;322(7297):1285-1288.

26. Zhelev Z, Peters J, Rogers M, Andrews R, McDonald T, Hyde C. Accuracy and validity of HbA1c Point of Care Testing: A review of the scientific evidence and guidelines. Exeter Test Group v3. Public Health England, University of Exeter Medical School, 2020.

27. Hirst JA, McLellan JH, Price CP, English E, Feakins BG, Stevens RJ, et al. Performance of pointof-care HbA1c test devices: aplications for use in clinical practice - a systematic review and metaanalysis. Clin Chem Lab Med. 2017;55:167-180.

28. Weykamp C. HbA1c: A review of analytical and clinical aspects. Ann Lab Med. 2013;33:393-400.

29. Heinemann L, Freckmann G. Quality of HbA1c measurement in the practice. The German perspective. J Diabetes Sci Technol. 2015;9(3):687-695.

30. Ørvim Sølvik U, Risøy AJ, Kjome RLS, Sandberg S. Quality control of Norwegian pharmacy HbA1c testing: a modest beginning. J Diabetes Sci Technol. 2018;12(4):753-61.

31. Hersberger KE, Botomino A, Mancini M, Bruppacher R. Sequential screening for diabetesevaluation of a campaign in Swiss community pharmacies. Pharm World Sci. 2006;28(3):171-179.

32. Krass I, Mitchell B, Clarke P, Brillant M, Dienaar R, Hughes J, et al. Pharmacy diabetes care program: analysis of two screening methods for undiagnosed type 2 diabetes in Australian community pharmacy. Diabetes Res Clin Pract. 2007;75(3):339-347. 
33. Fikri-Benbrahim N, Martínez-Martínez F, Saéz-Benito L, Luque BS, Corpas JPG, Moullin JC, et al. Assessment of a screening protocol for type 2 diabetes in com-munity pharmacy. The DiabNow Study. Diabetes Res Clin Pract. 2015;108(3):e49-e52.

34. Fornos-Pérez JA, Andrés-Rodríguez NF, Andrés-Iglesias JC, Luna-Cano R, García-Soidán J, Lorenzo-Veiga B, et al. Detection of people at risk of diabetes in community pharmacies of Pontevedra (Spain) (DEDIPO). Endocrinol Nutr. 2016;63(8):387-396.

35. Barron E, Misra S, English E, John WG, Sampson M, Bachmann MO, et al. Experience of point-ofcare HbAlc testing in the English National Health Service Diabetes Prevention Programme: an observational study. BMJ Open Diab Res Care. 2020;8:e01703.

36. Van Raalten F, Hiemstra YL, Keulen N, van Duivenvoorde Y, Stoecklein K, Verhagen EA, et al. Level of agreement of point-of-care and laboratory HbA1c measurements in the preoperative outpatient clinic in non-diabetic patients who are overweight or obese. J Clin Monit Comput. 2019;33:1139-1144. 


\title{
Usklađenost POCT metode sa potpuno automatizovanom metodom za određivanje HbA1c
}

\author{
Neda Milinković ${ }^{1 *}$, Marija Sarić Matutinović ${ }^{1}$, \\ Gordana Dmitrašinović ${ }^{1}$, Svetlana Ignjatović ${ }^{1,2}$
}
${ }^{1}$ Univerzitet u Beogradu - Farmaceutski fakultet, Katedra za medicinsku biohemiju, Vojvode Stepe 450, 11221 Beograd, Srbija
${ }^{2}$ Univerzitetski klinički centar Srbije, Centar za medicinsku biohemiju, Višegradska 26, 11000 Beograd, Srbija

*Autor za korespondenciju: Neda Milinković, e-mail: nedan@pharmacy.bg.ac.rs

\section{Kratak sadržaj}

Prethodna istraživanja sugerišu da je ,point-of-care“ metoda (POCT) za određivanje glikoziliranog hemoglobina (HbA1c) dijagnostički test koji može biti adekvatna alternativa merenju HbA1c u laboratoriji. Glavni cilj ovog istraživanja bio je da se ispitaju analitičke karakteristike nove INCLIX POCT metode za određivanje HbAlc kako bi se testirale karakteristike izvođenja pre uvođenja ove metode $\mathrm{u}$ rutinsku upotrebu. HbA1c je meren $\mathrm{u}$ duplikatu u 44 uzorka EDTA krvi paralelno na INCLIX POCT uređaju (Sugitech, Inc.) i automatskim turbidimetrijskim imunoinhibicijskim testom na Olympus AU400 biohemijskom analizatoru (Beckman Coulter). Nepreciznost u seriji bila je 7,58\%, nepreciznost između serija bila je 6,63\% i 6,22\%, a nepreciznost iz dana u dan bila je 8,80\% i 7,51\%. Ukupna laboratorijska nepreciznost bila je u slaganju sa podacima koje je naveo proizvođač. Izračunat je statistički značajan Pearsonov koeficijent korelacije $\left(r=0,871, P<0,01\right.$; linearni $\left.\mathrm{R}^{2}=0,757\right)$. Demingovom regresionom analizom dobijena je sledeća jednačina: $y=-1,80+1,304 x$. Naši rezultati ukazuju na statistički značajnu korelaciju, linearnu povezanost i značajan stepen kompatibilnosti između dve analizirane metode. Međutim, potvrđen je negativan bias vrednosti HbA1c određenih na POCT analizatoru u odnosu na Olympus AU400, što ističe potrebu za standardizacijom INCLIX metode.

Ključne reči: HbA1c, POCT, dijabetes, Demingova regresija 